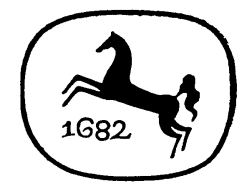

Von MaInz Nach WeIMaR

(1793-1919) 
Jost Hermand

\title{
Von MaInZ NACH WeIMaR
}

\author{
(1793-1919)
}

STUDIEN

ZUR Deutschen Literatur

MCMLXIX

J. B. Metzlersche Verlagsbuchhandlung

STUTTGART 
ISBN 978-3-476-98971-0 ISBN 978-3-476-98970-3 (eBook)

DOI 10.1007/978-3-476-98970-3

(C) 1969 Springer-Verlag GmbH Deutschland

Ursprünglich erschienen 1969 bei J. B. Metzlersche Verlagsbuchhandlung

und Carl Ernst Poeschel Verlag GmbH in Stuttgart 


\section{INHALTSVERZEICHNIS}

Vorbemerkung ............ . . 7

In Tyrannos. Über den politischen Radikalismus der sogenannten ,Spätaufklärung6 . . . . . . . . . . . . . . 9 Der ,Fall Geiger ${ }^{6}$. . . . . . . . . . . . . . 53

Napoleon im Biedermeier . . . . . . . . . . . . 99

Werthers Harzreise . . . . . . . . . . . . . . . . . 129

Das Junge Deutschland . . . . . . . . . . . . 152

Der deutsche Vormärz . . . . . . . . . . 174

Zur Literatur der Gründerzeit . . . . . . . . . . 211

Hauke Haien. Kritik oder Ideal des gründerzeitlichen Ủbermenschen? . . . . . . . . . . . . . 250

Gralsmotive um die Jahrhundertwende . . . . . . . 269

Expressionismus als Revolution . . . . . . . . 298

Anmerkungen .. . . . . . . . . . . 356

Namenregister .. . . . . . . . . . . 391 